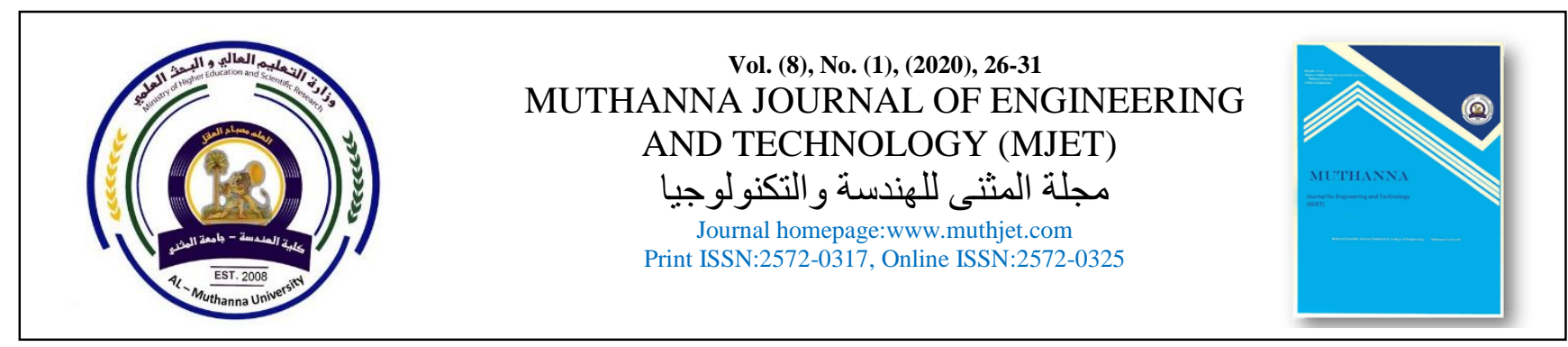

\title{
Design a Solar Powered Evaporative Cooling System D.C Motors with Peltier Device
}

\author{
Mohammed Hammoodi Jasim ${ }^{\mathrm{a},}$ Karrar A. Alakoul ${ }^{\mathrm{b}}$,Hussein Kareem Sultan ${ }^{\mathrm{c}}$ \\ ${ }^{a}$ Department of Electrical Engineering, Technical Institute/ Al-Rumaitha, Al- Furat Al- Awsat Technical \\ ${ }^{b, c}$ AL-Muthanna University, College of Engineering, Samawa
}

\section{ARTICLE INFO}

Received:20/02/2020

Accepted:10/05/2020

\section{Keywords}

Keywords, Solar energy, Centrifugal fan, Evaporative cooling, D.C pump, Battery and peltier

\begin{abstract}
ABSTRA CT
The research shows employing sundog cells for cooling process by design, progress of "evaporative cooling system ". All this to offer inexpensive method, devours more virtue as well as few energies in contrast with ordinary "evaporative cooling system". Consequently, this paper focuses "in the design and creation " direct current (DC) evaporative cooling system" incorporated with "photovoltaic (PV) system" formed from "PV panels, solar charger, converter, batteries" and insert to innermost of refrigerator by peltier . "Evaporative cooling system" depend on stellar also work in free areas. Also, solar energy is charge effectual, renewable, no environmental pollution. So finally fantastic method.
\end{abstract}




\section{INTRODUCTION}

The recent study shows how to provide ease circumstances for humanity by this piece of equipment. Because of uncomfortable hot and humid environment and weather. Thereby people need to preserve suitable thermal conditions. is by Room's temperature, humidity, also air speed determine thermal comfort, sunny heat (warm surfaces) or loss of warmth (wintry surfaces) play as a significant factor for thermal relieve. "Relative humidity (RH) is a measure of the moisture in the air, compared to the potential saturation level". heater air may embrace additional moisture. To condense moisture air, it reaches $100 \%$ humidity, known as dew point. According to atmospheric temperature, HVAC, other sources of heat or cool, sun loading determine building temperature. Since the room temperature lesser than body temperature so room occupants add heat. So solar energy solves all these problems because plentifully available in nature [1].

Since air conditioner (AC) takes a great amount of power as well as cost and power bills not reasonable for people in our country, that lead more researches to make it reasonable and lower power utilization. Causing These researches are basically the development recent technology; nevertheless, price factor consider less important. Nowadays AC means extra comfort. As heat rise public cannot pay to get it in summer. Public can require only coolers, ceiling fan as a need of hour [2].

Spray, permeable wetted pods provide rational heat energy through evaporative air cooling by evaporates little water. To decrease air dry-bulb temperature, raise humidity made up through heat as well as mass transferred between both water and air "at a constant wet- bulb temperature", the dry-bulb temperature of virtually soaked air close the around air wet-bulb temperature. The route is "adiabatic". Means no reasonable cooling present [3].

This document "aims to design and development solar evaporative cooling system" that might potentially offer enough cooling comfort, decrease environmental contact, less energy expenditure in buildings and effortless industrialized through simple and naturally existing resources.

\section{2. "PRESENT TECNOLOGY AVAILABLE"}

A lot of marked companies construct ease machineries/ equipment all over the world. Now days two types of technology used present:

(i) Using compressor, expansion apparatus to over an exchange between high pressure and low pressure conditions as well as evaporation of refrigerant in the closed tube. AC here provide the preferred comfort state, temperature plus control instrument. But this type not preferred in our country due to high power consumption and cost. (ii) Sprinkler using water evaporation and pump on silage pads as well as induced fan to draw air via the wet hey pads.

In order to provide best cooling air cooler, consider good choice in compare to a ceiling fan, however there is "no humidity controller and also no feedback mechanism through which $d$ specific desired temperature can be achieved". It may raise

health issues by more microbiological growth according to present of moist and humid atmosphere also. Since air cooler is less price and power consumption than air conditioner this cause less capital and running cost. Solar evaporative cooling system D.C motors with peltier. A new design to fill the gap of humidity and cost issues in this paper.

\section{"3. WORKING METHODOLOGY"}

Two parts is concerned in recent project:

\section{1. "Solar Energy Conversion"}

Using battery, converter and charge controller to provide solar energy conversion. Photoelectric effect converts sun light into electrical energy after it falls on solar panel. To store this energy This electrical energy stored in battery in the form of chemical energy. So between solar panel and battery charge controller employed to stop overcharging Figure [1].

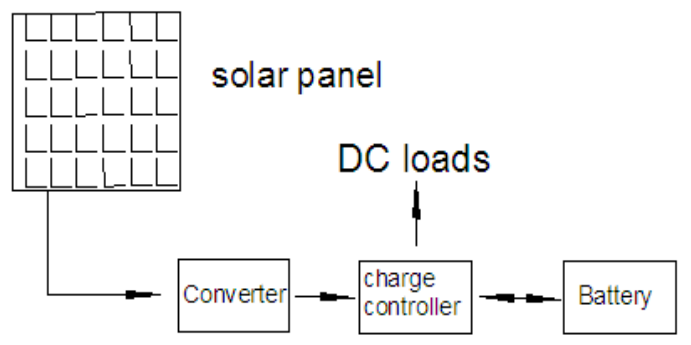

Fig 1. "Solar energy conversion process"

\subsection{Centrifugal fan cause cool air generation}

By using the converted to run the centrifugal fan. Cooling pads covers fans, in order to pass water on a precise rate. Heat transferred among water and air during hot air sucking by fan through cooling pads, in order to permit generated cool air to enter into the room Figure [2]. 


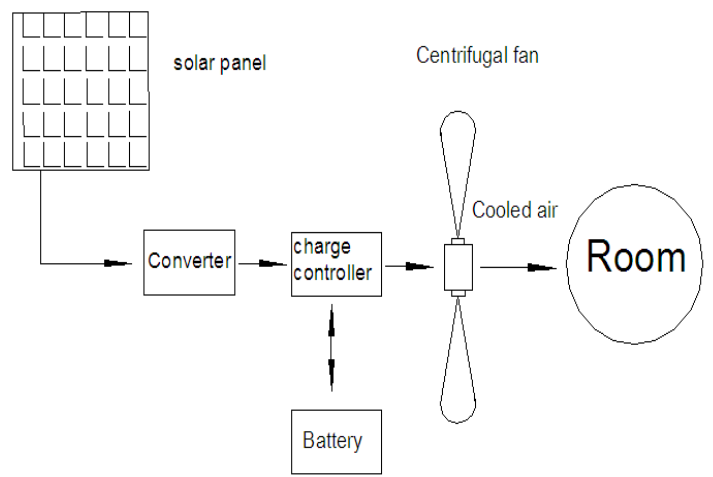

Fig 2."Process of cool air generation by centrifugal fan"

\section{WORKE MODEL OF THE PROJECT}

This idea is obsessed by solar energy. Solar panel, battery, peltier, fan, water pump converter, charge controller, and cooling pads are main components in this model. First by photovoltaic effect to convert sun light to electrical energy through solar panel. "The generated electrical energy is supplied to the battery for storage purpose through charge controller which prevents from power fluctuations".

The electric power necessary for the regulator to operate the fan, pump and peltier. The fan works to pull the cool air out of the refrigerator and push it into the living room. The water pump also pumps the water to the cooling pads. The peltier is used to cool the air inside the coolant with the help of heat sink connected outside and inside. Cooled and as a result warm air drawn through cooling pads is cooled inside the refrigerant and pushed into the living room Figure [3] and [4].

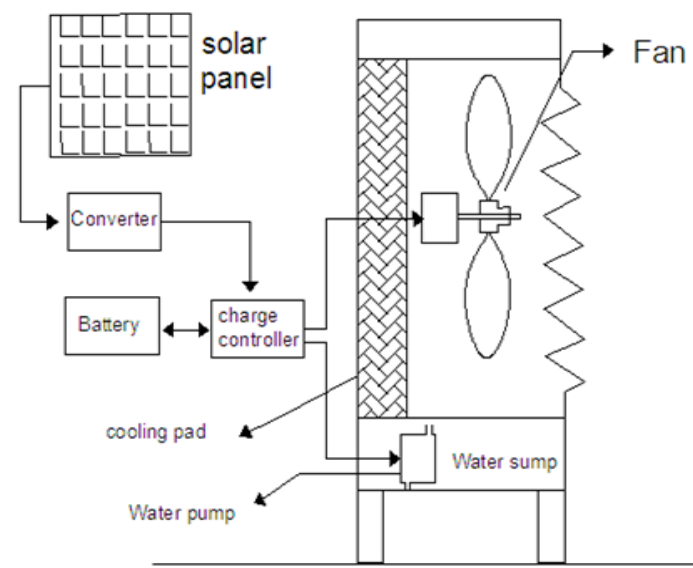

Fig 3. Solar powered air cooler

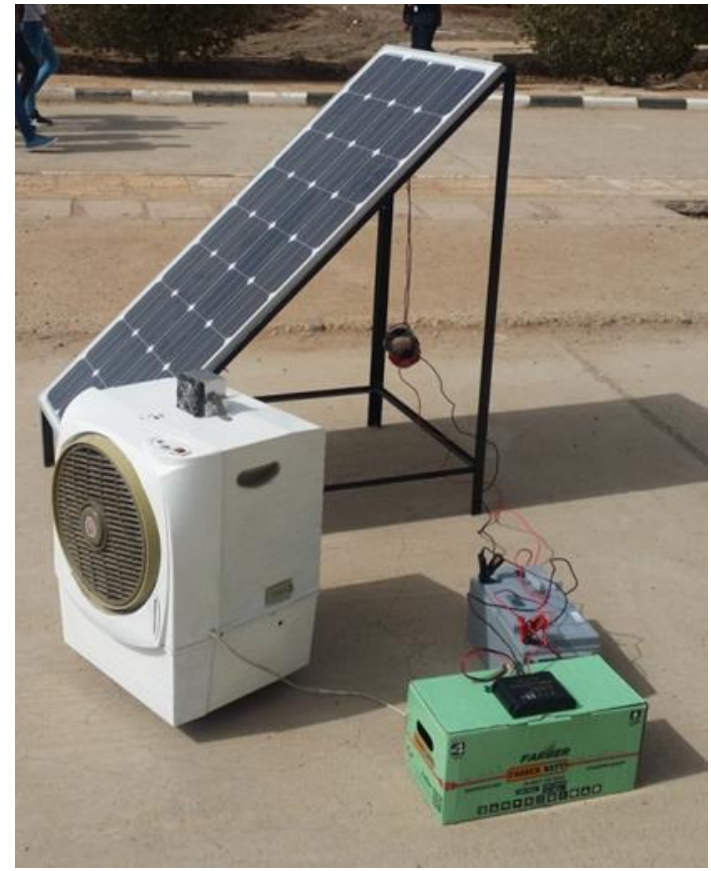

Fig 4. Real Work Environment

\section{DESIGN CONSIDERATIONS OF THE PROJECT}

\subsection{Capacity of the fan required}

Criteria: With supply of water through the cooling pads.

So, heat transfer between water and the air is given by following equation

$$
\left.\left.\mathrm{mw}^{*}(\mathrm{~T} 1-\mathrm{T} 2)=\text { ha1-ha2 }\right)-(\mathrm{w} 1-\mathrm{w} 2) \mathrm{T} 2\right]
$$

Where as

mw - Mass of water entering into the cooling pads per minute

$\mathrm{V}$ - Volume of air (m3) entering into the room per minute (min)

$\mathrm{V}_{\text {s1- }}$ Specific volume of air entering into the cooling room

ha1- Enthalpy per kg of dry air at $\mathrm{T}_{1}$

$\mathrm{h}_{\mathrm{a} 2}$ - Enthalpy per kg of dry air at $\mathrm{T}_{2}$

w1- Mass of vapour per $\mathrm{kg}$ of dry air at $\mathrm{T}_{1}$

w2- Mass of vapour per kg of dry air at $\mathrm{T}_{2}$

Considered conditions,

$\mathrm{T}_{1}=30{ }_{\circ} \mathrm{C} \& \mathrm{~T}_{2}=25{ }_{\circ} \mathrm{C}$

Relative humidity $=60 \%$

$\mathrm{m}_{\mathrm{w}}=2 \mathrm{~kg}$ of water per minute (assume)

From: Psychometric chart

ha1 $=72.5 \mathrm{KJ} / \mathrm{Kg}$ of dry air

$=17.31 \mathrm{kcal} / \mathrm{kg}$

ha2 $=56 \mathrm{KJ} / \mathrm{Kg}$ of dry air

$=13.37 \mathrm{kcal} / \mathrm{kg}$ 


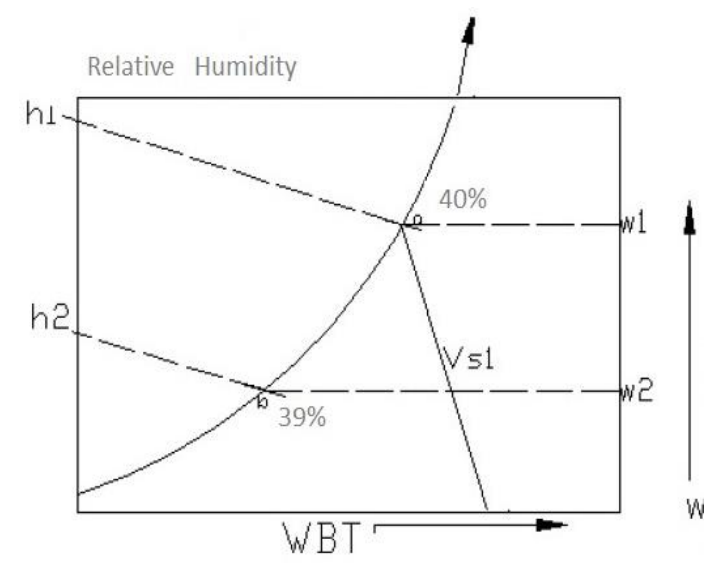

Fig 5. Psychometric Chart

$\mathrm{w}_{1}=0.016 \mathrm{grams} / \mathrm{kg}$ of dry air

$\mathrm{w} 2=0.012 \mathrm{grams} / \mathrm{kg}$ of dry air

$\mathrm{V}_{\mathrm{s} 1}=0.880 \mathrm{~m}^{3} / \mathrm{kg}$

Substituting above mentioned values in equation (1)

$2 *(30-25)=\frac{\boldsymbol{V}}{\mathbf{0 . 8 8 0}}[(17.31-13.37)-(0.016-0.012) * 25]$

$\mathrm{V}=2.291 \mathrm{~m}_{3} / \mathrm{min} \approx 2.5 \mathrm{~m}^{3} / \mathrm{min}$

So the fan capacity of $2.5 \mathrm{~m}^{3} / \mathrm{min}$ is selected.

\subsection{Capacity Solar Panel and Battery required}

Hence selected (Fan) Specification: 12v, 2.5A, $30 \mathrm{~W}$

So to run $30 \mathrm{~W}$ blower on for 1 hour will take $30 * 1=30 \mathrm{Wh}$ from the battery (Battery capacity is measured in Amp hours)

For $60 \mathrm{Ah}, 12 \mathrm{v}$ battery the watt hours are given by $P=V^{*} I$

$\mathrm{V}=12 \mathrm{v}$ and $\mathrm{I}=60 \mathrm{Ah}$

$\mathrm{P}=60 * 12=720 \mathrm{Wh}$

So, the $30 \mathrm{~W}$ centrifugal fan runs for $720 / 30=24 \mathrm{~h}$

This means the battery could supply $30 \mathrm{~W}$ fan for 24 hours.

\section{SYSTEM DESCRIPTION}

\subsection{Solar Panel:}

It is an apparatus works to accumulate and converts solar energy into either electricity or heat. It recognized as "Photovoltaic panels", thus generating electricity straight from sunlight "Solar thermal energy collection systems", is a process generating electricity throughout a "system of mirrors and fluidfilled tubes solar thermal collector", in order to heat water by heat solar hot water panel generated. It is "energy portal". Using solar photovoltaic arrays or solar cells to convert light from the sun directly into electricity consider a solar power technology, that light is converted into electrical power. Solar cells packaged in photovoltaic modules used for generating solar power, "often electrically connected in multiples as solar photovoltaic arrays to convert energy from the sun into electricity". "The photovoltaic solar panel is photons from sunlight knock electrons into a higher state of energy, creating electricity". Direct current electricity from light is produced by solar cells, necessary for power equipment or to recharge a battery. Thermal photovoltaic consider less common type of the technologies, that is using thermal radiation from some hot body rather than sun. Another characteristic for photovoltaic apparatus is to produce electricity in optical wireless power transmission.

\subsection{Fan:}

A detached fan is normally motorized by an electric motor. It's mainly connected directly to the motor's output, so gears or belts not needed. "Smaller fans are often powered by brushless DC motors". In recent document dc motor fans power fans of three blades.

\subsection{Pump:}

"The EBP (Electric Booster Pump) is a 'brushless' 12 volts, high-flow, magnetically-driven water pump". This characteristic means no need to wear out - ever - so pump is magnetically motivated by the motor, thus no requirements for shaft sealing. The impeller considers only moving part, also floating in the coolant. "The pump chamber is hermetically sealed for trouble-free operation". The EBP's simple in installation, "low-current draw, high flow capacity and long life make it ideal for a range of application".

\section{4 Battery:}

In recent study secondary rechargeable type battery used. Consist of one or more electrochemical cells, to accumulate chemical energy to provide electric current. "There are two types of batteries, primary (disposable) used one time due to irreversible reaction of chemicals and secondary (rechargeable) because of reversible chemical reaction, recharged by running a charging current through the battery but in the opposite direction of the discharge current. also known rechargeable batteries may be charged and discharged several times before consumed. Nevertheless, a number of batteries can be recycled. All types of batteries convert chemical energy to electrical energy.

\subsection{Peltier outcome}

A repeal truth proved against see beck outcome through Peltier, during electrical current movement through close circuit thermal energy absorbed in one contradictory metal junction leading cooling effect "QC" but in other junction discharged B making heat effect "QH". Figure 4, "the previous fact is adapted in order acquiring a diverse arrangement to 
demonstrate the Peltier outcome, an incident contrary of See beck result. In order for electrical current "I" to run in circuit need voltage "Ein" to go terminal T1, T2. All process can be opposite in different electrical current direction. Rx12"electrical resistance $=\mathrm{R}$ " causing Joel heating "Peltier effect reverse" causing net redaction of cooling "all above demonstrated by: -
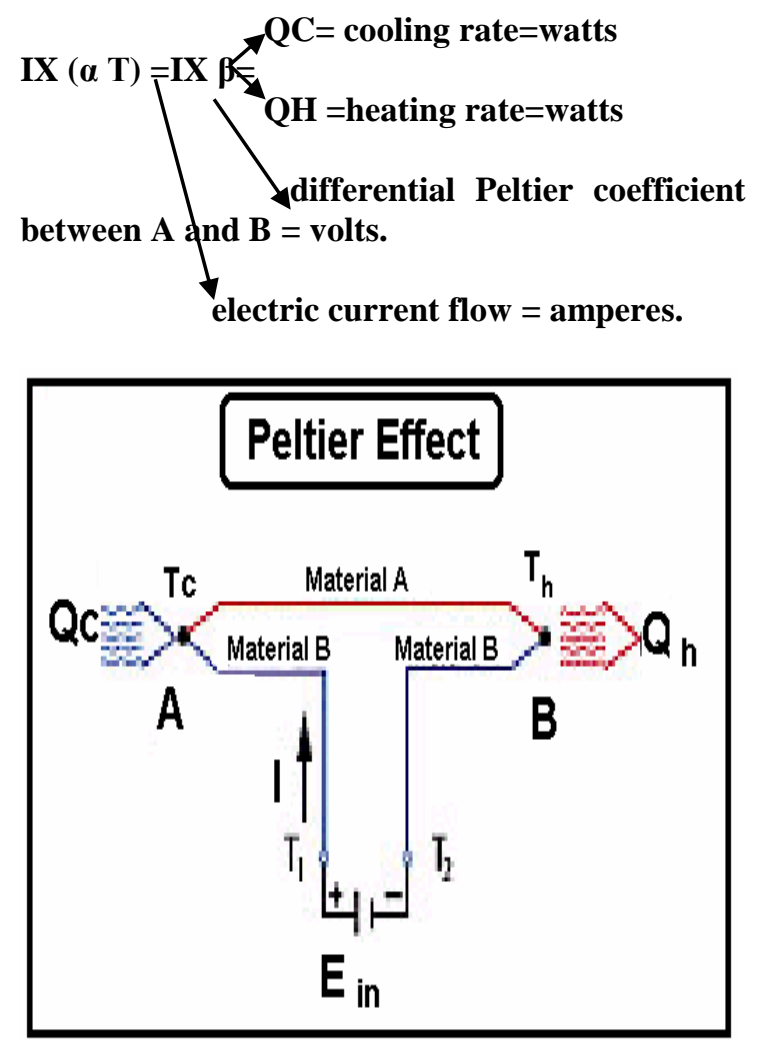

Fig 6. Peltier effect

\section{CALCULATION}

\subsection{Size of Cooler:}

Air delivery or Air displacement (in Cubic meter per minute $\mathrm{CMM})=$

[Area of room in square meter] $\mathrm{x}$ [height of room] $=(3 * 3 * 3) / 2=13.5 \mathrm{CMM}$

The factor 2 in denominator denotes that the air in the room is changed once in every 2 minutes.

\subsection{Heat load calculation:}

1BTU/ hr $=0.293$ Watt

1. Area of room $(\mathrm{BTU})=\mathrm{L} * \mathrm{~W} * 31.25$ $=3 * 3 * 31.25=281.25 \mathrm{BTU} / \mathrm{hr}$ $=82.4 \mathrm{Watt}$

2. North window without shading(BTU) $=\mathrm{L}^{*} \mathrm{~W} * 1.4 \mathrm{n}=1 * 1.5 * 1.4=2.1 \mathrm{BTU} / \mathrm{hr}$. $=0.6153 \mathrm{~W}$

3. South window without shading (BTU) $=\mathrm{L} * \mathrm{~W} * 1.4=1 * 1 * 1.4=1.4 \mathrm{BTU} / \mathrm{hr}$ $=0.4102 \mathrm{~W}$

4. Occupant (BTU)
$=$ No. of People $* 115=3 * 115$

$=345 \mathrm{BTU} / \mathrm{hr}=111.085 \mathrm{~W}$

Note: - assuming 115 BTU per person

a. Heat gain: Colour TV $=100 \mathrm{w} / 24 \mathrm{hr}$ $=4.1667 \mathrm{w} / \mathrm{hr}$

Computer $=6.25 \mathrm{w}$

b. Lighting Equip. $=2(22)+40$ $=84 \mathrm{~W} / 24 \mathrm{hr}=3.5 \mathrm{~W} / \mathrm{hr}$

5. Equipment (BTU) =Total equipment Watts*3.4

$=(4.1667+6.25) * 3.4=35.4167 \mathrm{BTU}$ $=10.3771 \mathrm{~W}$

6. Lighting (BTU)=Total Lighting Watts*4.25

$=3.5 * 4.25=14.875 \mathrm{BTU}=4.3583 \mathrm{~W}$

7. Total $(\mathrm{BTU})=\mathrm{eq}_{\mathrm{n}}(1+2+3+4+5+6)$ $=209.2459 \mathrm{~W}$

Air delivery $=13.5 \mathrm{CMM}$

Through air cooler $=13.5 * 163.17 \mathrm{BTU} / \mathrm{hr}$. $=13.5 * 163.17 * 0.293=645.42 \mathrm{~W}>$ Heat Load (i.e. 209.2459 W)

Psychometric Chart

Assuming: -

RH Std. air condition $=40-$ degree $\mathrm{c}$ DBT $\& 20$

Degree c WBT Expected $/$ Required condition $=20$ degree c DBT \& $55 \%$.

\section{RESULTS AND DISSCUSSION}

The output of the project is Comfort thermal conditions achieved in the living room. That is room temperature up to $21^{\circ} \mathrm{C}$ and relative humidity of $39 \%$ as well as implementation an evaporative cooler with a very low power and low cost. In addition, more than five refrigerants can be operated without the peltier and with the same values listed in Table [1] and the same idea can be applied to large-size refrigerators.

"TABLE 1. Cost estimation"

\begin{tabular}{llccc}
\hline "No". & $\begin{array}{l}\text { "Components } \\
\text { name" }\end{array}$ & "Qty". & "Desc". & $\begin{array}{c}\text { "Cost } \\
\text { (s.)" }\end{array}$ \\
\hline "1" & "Solar panel" & 1 & $\begin{array}{c}150 \mathrm{~W} \\
12 \mathrm{~V}\end{array}$ & 100 \\
2 & $\begin{array}{l}\text { Charge } \\
\text { controller }\end{array}$ & 1 & & 15 \\
& Battery & 1 & $65 \mathrm{~A} 12$ & 100 \\
3 & DC motor fan & 1 & $1.5 \mathrm{~A}$ & 15 \\
4 & & & $12 \mathrm{~V}$ & \\
& & & 1500 & \\
& & & R.P.M & \\
5 & DC Pump & 1 & $0.5 \mathrm{~A}$ & 12 \\
6 & Peltier Effect & 1 & $4 \mathrm{~A}$ & 5 \\
Total Cost & & & 247 \\
\hline
\end{tabular}




\section{CONCERT ANALYSIS}

"The output of solar evaporative cooler is achieving a lower room temperature".

All can have done in 2 hours inside opened area to examine the project.

The extent of the compartment is $3 \mathrm{~m} \times 3 \mathrm{~m} \times 3 \mathrm{~m}$.

Humidity meter used to compute both dry, wet bulb temperature by. "Readings: DBT and WBT" is done via experimental reading.

\begin{tabular}{|c|c|c|c|c|}
\hline $\begin{array}{c}\text { Duration } \\
\text { (min) }\end{array}$ & $\begin{array}{l}\text { TEMP. } \\
\text { ROOM }\end{array}$ & $\begin{array}{c}\text { "Dry } \\
\text { Bulb" } \\
\text { Temperat } \\
\text { e. "C" }\end{array}$ & $\begin{array}{c}\text { "Wet } \\
\text { Bulb" } \\
\text { Temperat } \\
e . \\
" C^{\prime \prime}\end{array}$ & $\begin{array}{c}\text { Humidit } \\
y \\
(\%)\end{array}$ \\
\hline 0 & 26 & 10.5 & 15.5 & 40 \\
\hline 30 & 24.6 & 9.7 & 14.5 & 39.7 \\
\hline 60 & 23.4 & 9.2 & 14.0 & 39.5 \\
\hline 90 & 23 & 9.0 & 13.8 & 39.3 \\
\hline 120 & 21 & 9.0 & 13.5 & 39 \\
\hline
\end{tabular}

\section{CONCLUSION}

It provides both cold, humidity. Peltier device fascinate air humidity, consider economical and efficient project to form ease appliance. "Solar Powered Evaporative cooling system" may escalate using a normal obtainable possession at home using few energy consuming and low operation cost. In future can develop Evaporative cooling system by using more than one Peltier device to decrease temperature as well as increase humidity.

This product is considered one of the important products in the markets, especially in the Iraqi markets, and for several reasons, including that it is an environmentally friendly project, that is, it does not produce any waste or gases that harm the environment, as well as the economic cost of this product and operate it continuously without the need for electrical energy, that is, it is suitable for villages and rural areas that cannot be delivered National electrical energy to it, and also considered suitable for schools and offices, and therefore considered an alternative to the problems of power outages.

\section{REFERENCES}

[1] Vijaykumar Kalwa, R. Prakash, "Design and Development of Solar Powered Air Cooler", International Journal of Science and Research (IJSR),Volume 3 Issue 6, June 2014, pages: 478-481 [2] Ashwani Sharma, Tushar Saxena, Priyank Pant, Shantanu Gandhi, "Design and Fabrication of Soler Evaporative cooling Air conditioner", International Journal of Research in Engineering and Technology, Volume: 05 Issue: 05 | May-2016, pages: $218-220$

[3] Farhan A. Khmamas, "Improving the Environmental Cooling for Air-coolers by using Thy Indirect- cooling Method", ARPN Journal of Engineering and Applied Sciences, Volume: 5, No. 2, February 2010, pages: 66-73

[4] Suvarna V.Mehere, KrunalP.Mudafale, Dr.Sunil.V.Prayagi, "Review of Direct Evaporative Cooling System with Its Applications", International Journal of Engineering Research and General Science, Volume 2, Issue 6, October-November, 2014, pages: $995-999$

[5] Gorle1, Wandhare, Anurag R. Khelkar, Ayush S. Bhoyar, Ashit S. Muley, "Solar Powered Evaporative Air Cooler with Cooling Cabin for Household Food Items",IOSR Journal of Mechanical and Civil Engineering (IOSRJMCE), Volume 13, Issue 2 Ver. IV (Mar- Apr. 2016), pages: 53-56

[6] Vipin Das, NidhinMj, MidhunUnnikrishnan, Nygin Jose, Rishikesh P., SuneethSukumaran, "Fabrication and Analysis of solar powered Air cooler", The International Journal Of Engineering And Science (IJES), Volume 5, Issue 1, 2016, pages:36 - 41

[7] Dave S. Steinberg "Cooling techniques for electronic equipment" $2^{\text {rd }}$ Edition, November 1980. 